\title{
APLIKASI UV SPECTROSCOPY DAN METODE SIMCA UNTUK KLASIFIKASI KOPI LIBERIKA TUNGKAL JAMBI DAN KOPI LIBERIKA PROBOLINGGO
}

\section{APPLICATION OF UV SPECTROSCOPY AND SIMCA METHOD FOR CLASSIFICATION OF TUNGKAL JAMBI LIBERICA COFFEE AND PROBOLINGGO LIBERICA COFFEE}

\author{
Sapto Kuncoro ${ }^{1}$, Meinilwita Yulia ${ }^{2}$, Diding Suhandy ${ }^{3 凶}$ \\ ${ }^{1}$ Jurusan Teknik Pertanian, Universitas Lampung \\ ${ }^{2}$ Jurusan Teknologi Pertanian, Politeknik Negeri Lampung \\ ${ }^{3}$ Spectroscopy Research Group (SRG) Jurusan Teknik Pertanian, Universitas Lampung \\ $\bowtie$ Komunikasi Penulis, email: diding.sughandy@fp.unila.ac.id \\ DOI:http://dx.doi.org/10.23960/jtep-lv10i1.49-56
}

Naskah ini diterima pada 6 Januari 2021; revisi pada 20 Februari 2021;

disetujui untuk dipublikasikan pada 2 Maret 2021

\begin{abstract}
Tungkal Composite Jambi Liberika Coffee is one of the top qualities of Indonesian coffees that has received a geographic indication certificate (IGs). With its limited production and high prices, currently Tungkal Jambi Liberika coffee is one of the coffees that is prone to being counterfeited. The counterfeiting of Tungkal Jambi Liberika coffee is increasingly difficult to identify, especially in the form of ground roasted coffee. This study evaluated the potential application of UV spectroscopy technology to classify Tungkal Jambi Liberika coffee (with geographic indications) and normal Probolinggo Liberika coffee (non-geographic indications). A total of 120 samples for each Liberika coffee were prepared weighing 1 gram for each sample. Spectra measurements were carried out in the form of a coffee solution. Spectral data were taken using a UV-visible spectrometer with a wavelength interval of 200-400 $\mathrm{nm}$ (Genesys ${ }^{T M} 10 \mathrm{~S}$ UV-Vis, Thermo Scientific, USA). By using the average transformed spectra in the 250-350 $\mathrm{nm}$ interval, the differences between the two types of Liberika coffee can be clearly seen, especially at some wavelength peaks, namely $270 \mathrm{~nm}, 300 \mathrm{~nm}, 315 \mathrm{~nm}$ and $346 \mathrm{~nm}$. The classification accuracy obtained for the SIMCA classification is 100\% for both Tungkal Jambi Liberika and Probolinggo Liberika coffee.
\end{abstract}

Keywords: authentication, classification accuracy, Tungkal Jambi Liberika coffee, SIMCA, UV Spectroscopy

\begin{abstract}
ABSTRAK
Kopi Liberika Tungkal Komposit Jambi merupakan salah satu kopi Indonesia berkualitas yang telah mendapatkan sertifikat geografis (IGs). Dengan produksi yang masih terbatas dan harga yang tinggi, saat ini kopi Liberika Tungkal Jambi merupakan salah satu kopi yang rawan dipalsukan. Pemalsuan kopi Liberika Tungkal Jambi semakin sulit diidentifikasi terutama pada bentuk kopi bubuk. Pada penelitian ini dilakukan evaluasi potensi aplikasi teknologi UV spectroscopy untuk mengklasifikasikan kopi Liberika Tungkal Jambi (dengan indikasi geografis) dan kopi Liberika Probolinggo biasa (non-indikasi geografis). Sebanyak 120 sampel untuk masingmasing kopi Liberika disiapkan dengan berat 1 gram untuk setiap sampel. Pengukuran spektra dilakukan dalam bentuk larutan kopi. Data spektra diambil menggunakan spektrometer $U V$-visible dengan panjang gelombang 200$400 \mathrm{~nm}$ (Genesys ${ }^{\mathrm{TM}} 10 \mathrm{~S}$ UV-Vis, Thermo Scientific, USA). Dengan menggunakan spektra rataan hasil transformasi di interval 250-350 nm, maka perbedaan kedua jenis kopi Liberika dapat jelas terlihat terutama di beberapa puncak panjang gelombang yaitu $270 \mathrm{~nm}, 300 \mathrm{~nm}, 315 \mathrm{~nm}$ dan $346 \mathrm{~nm}$. Akurasi klasifikasi yang diperoleh untuk klasifikasi SIMCA adalah 100\% baik untuk kopi Liberika Tungkal Jambi maupun untuk kopi Liberika Probolinggo.
\end{abstract}

Kata Kunci: akurasi klasifikasi, Kopi Liberika Tungkal Jambi, SIMCA, uji keaslian, UV-Spectroscopy 


\section{PENDAHULUAN}

Dari sekitar 124 varietas kopi yang telah berhasil diidentifikasi oleh Davis et al. (2011), hanya beberapa saja yang saat ini populer. Di Indonesia misalnya, terdapat tiga varietas kopi yang memiliki nilai ekonomi tinggi dan banyak dibudidayakan baik dalam skala perkebunan rakyat (smallholder coffee) maupun perusahaan/perkebunan besar (estates coffee) yaitu varietas kopi Arabika (Coffea arabica), kopi Robusta (Coffea canephora) dan kopi Liberika (Coffea liberica). Menurut Sianipar (2017), secara nasional di tahun 2014 total luas produksi kopi Liberika hanya sekitar tiga ribuan hektar, dengan total produksi sekitar 1214 ton. Secara keseluruhan jumlah ini masih relatif kecil kontribusinya terhadap produksi kopi nasional yang masih didominasi oleh kopi Arabika dan Robusta. Meskipun demikian kopi Liberika memiliki beberapa kelebihan seperti kemampuan beradaptasi dengan tanah gambut sehingga berpeluang untuk peningkatan produktivitas khususnya di Indonesia mengingat lahan gambut yang masih tersedia sangat luas. Kopi Liberika Tungkal Komposit Jambi (Coffea liberica Bull ex Hiern) atau Liberika Tungkal Jambi sendiri ditanam di daerah gambut dengan tingkat keasaman tanah yang cukup tinggi. Kemudian dari sisi cita rasa kopi Liberika secara umum memiliki cita rasa unik yang berbeda dengan kopi Arabika dan Robusta dengan hasil uji mencapai nilai kesukaan (preferensi) ratarata 7 atau mutu cita rasa bagus. Kopi Liberika secara umum memiliki kadar kafein mirip kopi Arabika (relatif rendah) (Sianipar, 2017). Selain itu kopi Liberika bisa dibudidayakan di lahan dataran rendah (kurang dari $700 \mathrm{mdpl}$ ) sehingga lebih memudahkan dalam proses perawatan dan peningkatan produksi di mana ukuran biji kopi Liberika lebih besar dibandingkan kopi Robusta dan Arabika.

Indikasi geografis atau IGs merupakan salah satu sistem proteksi terhadap produk pertanian yang memiliki keunggulan baik terkait dengan faktor alam maupun faktor manusia atau kombinasi dari kedua faktor tersebut yang memberikan reputasi, kualitas, dan karakteristik tertentu pada barang dan/atau produk yang dihasilkan. Kopi Liberika Tungkal Jambi secara resmi telah mendapatkan sertifikat IGs pada tahun 2015 (ID
G 000000032). Kopi Liberika Tungkal Jambi diperdagangkan dengan harga hampir dua kali lipat harga kopi biasa (DGIP, 2013). Dengan produksi yang masih terbatas dan harga yang tinggi, saat ini kopi Liberika Tungkal Jambi merupakan salah satu kopi yang rawan dipalsukan. Pemalsuan kopi Liberika Tungkal Jambi semakin sulit diidentifikasi terutama pada bentuk kopi bubuk.

Beberapa metode analisis berbasis pengukuran spektra (spectroscopy) telah diujicobakan untuk keperluan uji keaslian kopi bubuk. Misalnya Baqueta et al. (2021) menggunakan near infrared spectroscopy dan kemometrika untuk uji keaslian kopi bubuk dengan akurasi klasifikasi sebesar 84-100\%. Raman spectroscopy dan kemometrika juga digunakan untuk uji keaslian kopi bubuk Arabika dan Robusta dari tiga origin yaitu Asia, Afrika dan Amerika Selatan (Keidel et al., 2010). Dankowska et al. (2017) menggunakan data spektra fluorescence dan kemometrika untuk membedakan kopi Arabika, Robusta dan campuran keduanya dengan persentase ketepatan klasifikasi lebih dari 90\%. Suhandy \& Yulia (2018) juga menggunakan fluorescence spectroscopy untuk proses diskriminasi beberapa kopi spesialti asal Indonesia. Hanya saja sebagian besar metode spectroscopy tersebut melibatkan spektrometer yang mahal dan sulit untuk proses pengembangan teknologinya. Salah satu metode spectroscopy yang cukup terjangkau dari sisi biaya adalah $U V$ spectroscopy. Teknologi ini sudah digunakan untuk uji keaslian kopi (Diding Suhandy \& Yulia, 2017), teh (Aboulwafa et al., 2019) dan madu (Roshan et al., 2013). Sejauh ini belum ada penelitian terkait aplikasi teknologi $U V$ spectroscopy dan SIMCA untuk uji keaslian kopi Liberika Tungkal Jambi. Pada penelitian ini dilakukan evaluasi potensi UV spectroscopy untuk mengklasifikasikan kopi Liberika Tungkal Jambi dengan indikasi geografis dan kopi Liberika Probolinggo biasa (non-indikasi geografis).

\section{BAHAN DAN METODE}

\subsection{Sampel Kopi}

Sampel kopi Liberika yang digunakan sebagai bahan penelitian adalah sampel kopi Liberika 
Tungkal Jambi dengan indikasi geografis dan kopi Liberika Probolinggo Jawa Timur yang belum mendapatkan indikasi geografis. Kopi Liberika Tungkal Jambi diperoleh dari petani kopi di Desa Bram Itam Raya, Kecamatan Bram Itam Kabupaten Tanjung Jabung Barat Provinsi Jambi dengan ketinggian tanam kopi sekitar 10 mdpl (dataran rendah). Kopi Liberika Probolinggo diperoleh dari petani kopi di Kelurahan Sukoharjo Kecamatan Kangaran Kota Probolinggo. Kopi Liberika Tungkal Jambi sebagai salah satu kopi dengan sertifikat indikasi geografis diproses dengan cara proses semi-dry atau disebut juga proses honey. Untuk kopi Liberika Probolinggo diproses dengan proses kering (natural). Seluruh sampel dibeli dalam kondisi green bean dalam kemasan $1 \mathrm{~kg}$ dan disangrai di Laboratorium Rekayasa Bioproses dan Pasca panen (RBPP) menggunakan mesin sangrai dengan suhu $210-220^{\circ} \mathrm{C}$ selama 15 menit. Jumlah sampel kopi Liberika Tungkal Jambi dan kopi Liberika Probolinggo yang digunakan untuk penelitian ini adalah masingmasing sebanyak 120 sampel dengan berat $1 \mathrm{~g}$ untuk setiap sampel.

\subsection{Proses Ekstraksi Kopi Bubuk}

Setelah disangrai, kopi kemudian digiling menggunakan Sayota home coffee grinder (tipe SCG 178) dan diayak menggunakan Meinzer II sieve shaker (CSC Scientific Company, Inc. USA) dengan mesh 40 (ukuran partikel kopi bubuk $0.420 \mathrm{~mm}$ ). Sebanyak 120 sampel untuk masingmasing kopi Liberika disiapkan dengan berat 1 gram untuk setiap sampel. Pengukuran spektra dilakukan dalam bentuk larutan kopi. Larutan kopi dibuat dengan menggunakan prosedur ekstraksi seperti yang dilakukan riset sebelumnya (Diding Suhandy \& Yulia, 2017). Prosedur tersebut meliputi: pemberian air panas (bersuhu sekitar $90-98^{\circ} \mathrm{C}$ ) sebanyak 50 $\mathrm{mL}$, pengadukan, penyaringan, pengenceran dengan perbandingan 1: 20 (volume: volume) dan pengadukan hasil pengenceran (Diding Suhandy \& Yulia, 2017).

\subsection{Pengambilan Spektra}

Sebanyak $3 \mathrm{~mL}$ sampel larutan kopi hasil pengenceran diambil dan diteteskan ke dalam kuvet kuarsa berukuran $10 \mathrm{~mm}$. Data spektra diambil menggunakan spektrometer $U V$-visible dengan panjang gelombang 200-400 nm
(Genesys $^{\text {TM }}$ 10S UV-Vis, Thermo Scientific, USA). Mode transmitan digunakan selama proses pengambilan data spektra.

\subsection{Metode SIMCA}

Sebelum dilakukan analisis perhitungan SIMCA, perhitungan PCA dilakukan terlebih dahulu menggunakan seluruh sampel dengan metode validasi silang penuh (full-cross validation) atau disebut juga sebagai metode leave-one-out-cross (LOOC) validation. Hasil analisis PCA yang digunakan untuk analisis adalah nilai skor dan $x$ loadings. Untuk SIMCA, model SIMCA masingmasing kelas yaitu kelas kopi Liberika Tungkal Jambi dan kelas kopi Liberika Probolinggo dibangun dengan cara menghitung PCA untuk sampel kalibrasi setiap kelas. Sampel prediksi digunakan untuk menghitung akurasi klasifikasi menggunakan model SIMCA yang dibangun. Untuk memperbaiki kualitas spektra, dua algoritma perbaikan data spektra digunakan secara sekaligus untuk mengubah spektra original menjadi spektra transformasi yaitu standard normal variate (SNV) dan SavitzkyGolay derivation dengan jumlah segmen sebesar 5 dan ordo sebesar 2 (SG 1d 5s). Untuk penjelasan lebih lengkap terkait PCA dan SIMCA serta analisis perbaikan spektra dapat dirujuk beberapa artikel yang sudah dipublikasikan (Pomerantsev \& Rodionova, 2014, 2020). Seluruh perhitungan kemometrika termasuk PCA dan SIMCA dilakukan menggunakan pengolah data the Unscrambler versi 9.8 (CAMO, Oslo, Norwegia).

\section{HASIL DAN PEMBAHASAN}

\subsection{Analisis Spektra Kopi Liberika}

Gambar 1 merupakan spektra original (spektra asli hasil pengambilan spektra) seluruh sampel untuk kopi Liberika Tungkal Jambi dan Probolinggo pada panjang gelombang 200-400 $\mathrm{nm}$. Secara visual tampak bahwa spektra kedua jenis kopi Liberika sangat identik dan sangat sulit membedakan kedua jenis kopi Liberika tersebut berdasarkan data spektra original. Pada pengukuran spektra menggunakan mode transmitan, intensitas absorbans yang terlalu tinggi atau terlalu rendah sebaiknya tidak dilibatkan dalam proses analisis spektra. Spektra dengan intensitas absorbans terlalu tinggi terlihat di interval 200-250 $\mathrm{nm}$ dan menunjukkan 
potensi data bersifat noisy di mana di interval 200-250 $\mathrm{nm}$ sebagian besar cahaya sebenarnya diserap oleh sampel sehingga informasi yang diteruskan ke dalam detektor merupakan informasi noisy yang tidak berhubungan langsung dengan sampel. Sedangkan intensitas absorbans yang terlalu rendah atau mendekati nol terlihat di interval 350-400 nm. Spektra tersebut mengandung sedikit sekali informasi sampel.

Untuk memperjelas perbedaan spektra kedua jenis kopi maka dibuat spektra rataan untuk spektra original dan hasil transformasi seperti ditunjukkan di Gambar 2. Dengan menggunakan spektra rataan hasil transformasi maka perbedaan kedua jenis kopi Liberika dapat terlihat terutama di beberapa puncak panjang gelombang di interval $250-350 \mathrm{~nm}$ yaitu panjang gelombang $270 \mathrm{~nm}, 300 \mathrm{~nm}, 315 \mathrm{~nm}$ dan 346 nm. Panjang gelombang tersebut berkorelasi dengan absorbansi beberapa senyawa penting pada kopi bubuk Arabika dan Robusta dan sejalan dengan hasil riset sebelumnya. Suhandy \& Yulia (2019) melaporkan interval panjang gelombang 250-450 nm mengandung informasi yang memadai untuk membedakan dua kopi Arabika spesialti di Sulawesi Selatan. Yulia \& Suhandy (2018) menggunakan interval spektra UV 230-400 nm untuk klasifikasi kopi bubuk dengan perbedaan masa simpan (fresh vs expired) dengan akurasi sebesar $100 \%$.

\subsection{PCA}

Gambar 3 merupakan plot nilai skor PCA untuk dua komponen utama yaitu PC1 dan PC2 untuk spektra hasil transformasi di interval 200-400 $\mathrm{nm}$ dan $250-350 \mathrm{~nm}$. Untuk interval penuh yaitu 200-400 nm, PC1 dan PC2 secara kumulatif mampu menjelaskan $87 \%$ varian data.
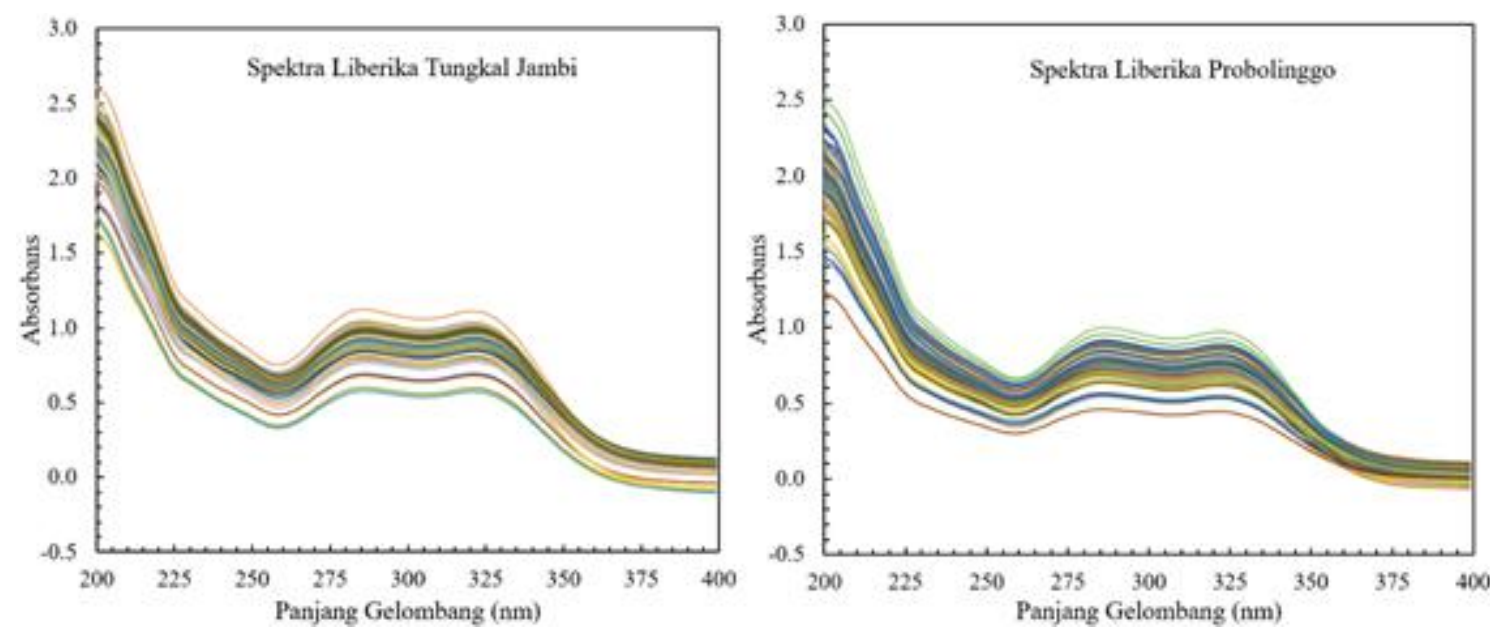

Gambar 1. Spektra Original Sampel Kopi Liberika Tungkal Jambi dan Probolinggo di Interval 200$400 \mathrm{~nm}$
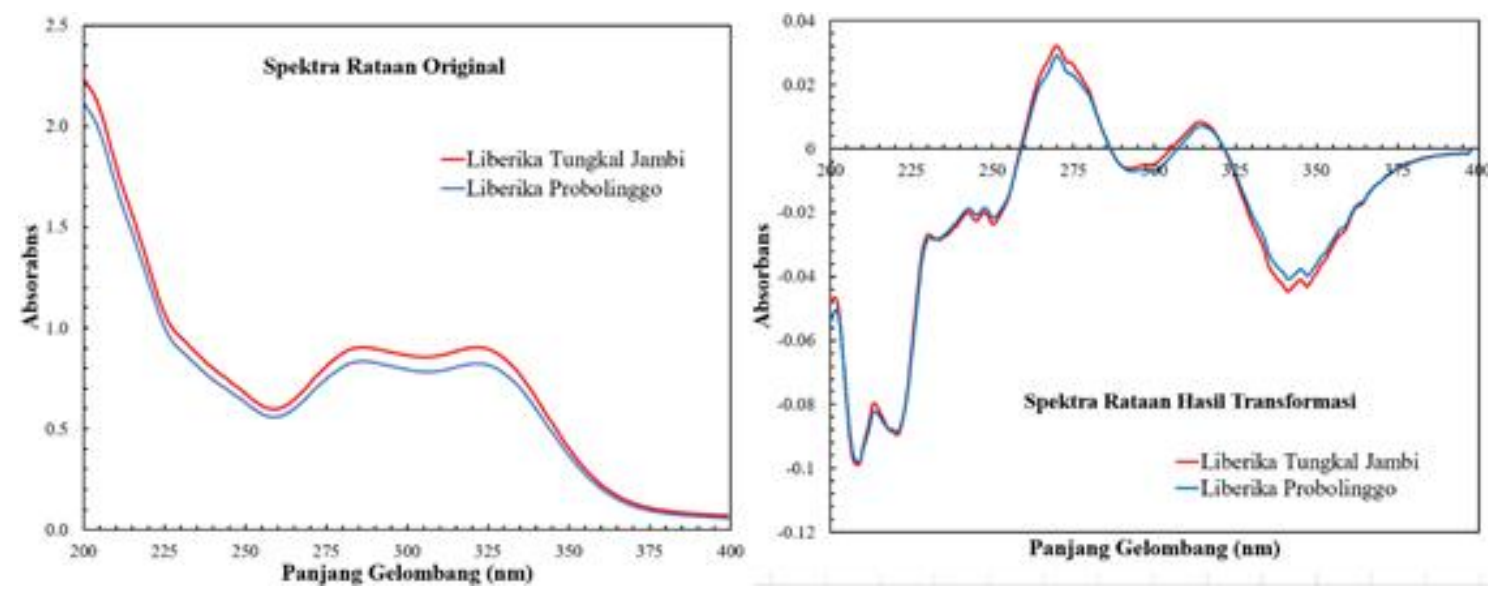

Gambar 2. Spektra Rataan Original dan Hasil Transformasi Sampel Kopi Liberika Tungkal Jambi dan Probolinggo di Interval 200-400 nm 
Pemisahan sampel kopi Liberika Tungkal Jambi dan Probolinggo terutama terjadi di sepanjang PC1 yang mampu menjelaskan sebagian besar varian data yaitu sebesar 71\%. Dapat dilihat bahwa proses pemisahan sampel masih belum sepenuhnya berhasil di mana untuk interval 200$400 \mathrm{~nm}$, sebagian besar sampel kopi Liberika Tungkal Jambi memiliki nilai skor PC1 yang sama. Hasil pemisahan lebih baik diperoleh menggunakan interval terpilih yaitu 250-350 nm. PC1 mampu menjelaskan varian data spektra sebesar 85\% dan kedua kopi Liberika terpisah di sepanjang sumbu PC1. Sebagian besar sampel kopi Liberika Tungkal Jambi terletak di PC1 negatif sedangkan sebagian besar sampel kopi Liberika Probolinggo terletak di PC1 positif. Hasil ini menunjukkan pentingnya pemilihan interval panjang gelombang yang terlibat dalam analisis PCA.
Selain plot nilai skor, hasil analisis PCA juga dinyatakan dalam bentuk plot nilai $x$-loading seperti ditunjukkan di Gambar 4. Untuk plot ini panjang gelombang dengan nilai $x$-loadings yang tinggi berkorelasi dengan signifikansi panjang gelombang tersebut pada struktur PCA. Berdasarkan Gambar 4 ada beberapa panjang gelombang dengan nilai $x$-loadings tinggi. Untuk PC1 ada di panjang gelombang $270 \mathrm{~nm}, 305 \mathrm{~nm}$, dan $340 \mathrm{~nm}$. Untuk PC2 ada di panjang gelombang $260 \mathrm{~nm}, 280 \mathrm{~nm}$ dan $325 \mathrm{~nm}$.

\subsection{Hasil SIMCA}

Model SIMCA untuk kelas kopi Liberika Tungkal Jambi dan model SIMCA untuk kelas kopi Liberika Probolinggo dibangun menggunakan sampel kalibrasi (72 sampel untuk masingmasing kelas). Model ini kemudian digunakan untuk klasifikasi kopi Liberika Tungkal Jambi
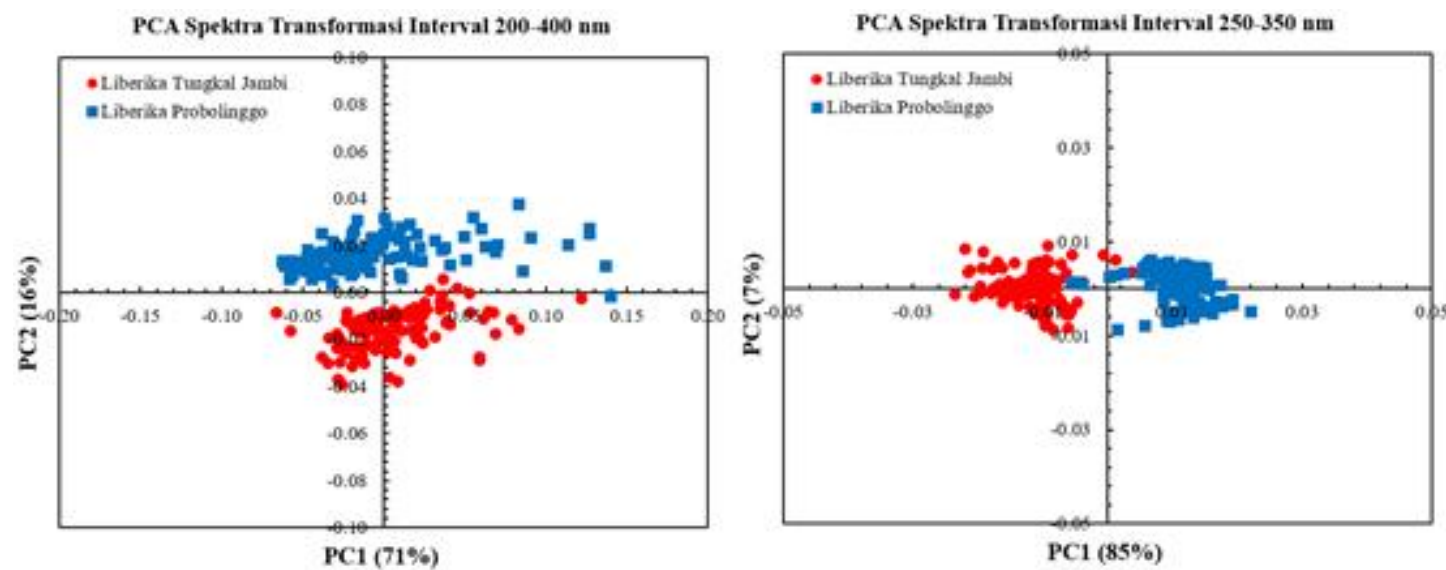

Gambar 3. Plot Skor PCA untuk Dua Komponen Utama (PC1 dan PC2) Menggunakan Spektra Hasil Transformasi di Interval 200-400 nm dan 250-350 nm

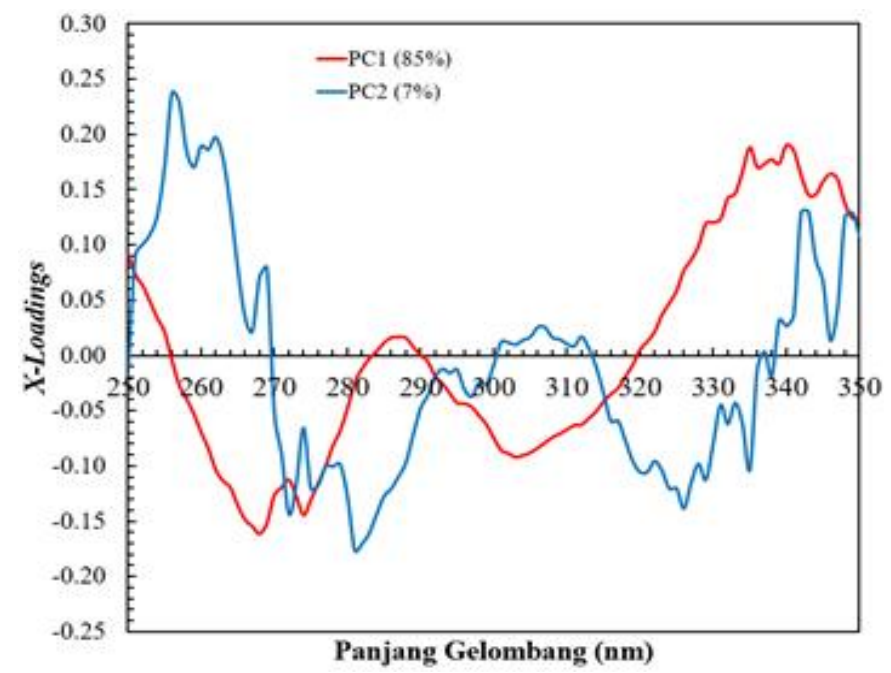

Gambar 4. Plot $x$-loadings PCA untuk Dua Komponen Utama (PC1 dan PC2) Menggunakan Spektra Hasil Transformasi di Interval 250-350 nm 


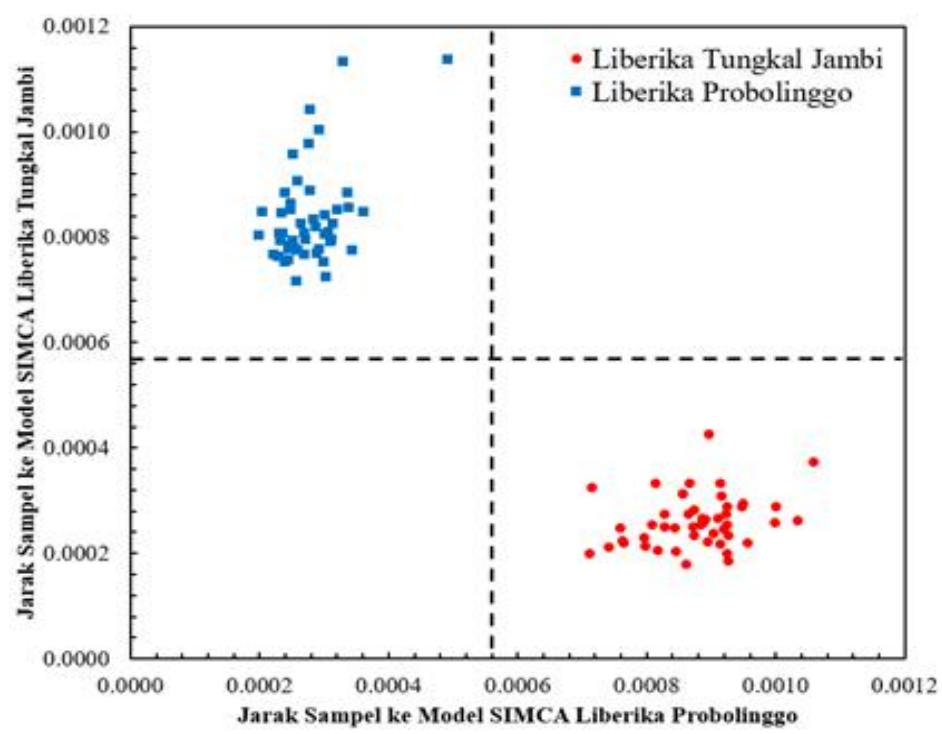

Gambar 5. Plot Cooman dengan nilai Signifikansi $0.05(\alpha=0$. 05) untuk Hasil Prediksi Kelas Liberika Tungkal Jambi dan Kelas Liberika Probolinggo

dan Probolinggo. Model SIMCA tiap kelas dibangun menggunakan metode full-cross validation. Untuk menguji kinerja model SIMCA yang dibangun maka dilakukan klasifikasi sampel kopi prediksi menggunakan model SIMCA yang dibangun. Hasilnya ditunjukkan di Gambar 5 dalam bentuk plot Cooman dengan nilai signifikansi $0.05 \quad(\alpha=0.05)$.

Garis putus-putus (Gambar 5 ) menunjukkan garis keanggotaan untuk kelas kopi Liberika Tungkal Jambi dan kelas kopi Liberika Probolinggo. Dari Gambar 5 terlihat bahwa seluruh sampel prediksi yaitu 48 sampel kopi Liberika Tungkal Jambi dan 48 sampel kopi Liberika Probolinggo terletak di pojok kanan bawah dan pojok kiri atas yang menunjukkan seluruh sampel berhasil diklasifikasikan sesuai dengan kelasnya masing-masing. Akurasi klasifikasi yang diperoleh adalah 100\% baik untuk kopi Liberika Tungkal Jambi maupun untuk kopi Liberika Probolinggo.

Hasil SIMCA menunjukkan jarak model antar kelas kopi Liberika Tungkal Jambi dan kelas kopi Liberika Probolinggo sebesar 12.471. Menurut Meza-Márquez et al, (2010), dua kelas dikatakan berbeda dan terpisah dengan baik jika memiliki jarak model lebih dari 3. Hasil SIMCA dengan jarak model 12.471 menunjukkan mode SIMCA yang dibangun berhasil membedakan kelas kopi Liberika Tungkal Jambi dan kopi Liberika Probolinggo dengan sangat baik.
Hasil penelitian ini menunjukkan efektivitas penggunaan teknologi UV spectroscopy dan metode SIMCA untuk klasifikasi kopi Liberika Tungkal Jambi yang memiliki sertifikat indikasi geografis dengan kopi Liberika Probolinggo yang belum mendapatkan indikasi geografis. Pada penelitian sebelumnya, (Diding Suhandy \& Yulia, 2017) menggunakan UV-Visible spectroscopy dan SIMCA untuk membedakan kopi lanang dan kopi biasa dengan hasil klasifikasi sebesar 100\%. Yulia et al. (2018) menggunakan UV-Visible spectroscopy dan metode SIMCA untuk mengklasifikasikan kopi dekafeinasi dan kopi non-dekafeinasi dengan akurasi mencapai $100 \%$. Santos et al. (2012) menggunakan near infrared spectroscopy dan metode SIMCA untuk membedakan kopi bubuk dari beberapa kota di Brasil dengan tiga jenis varian kopi (tradisional, gourmet dan dekafeinasi) dengan hasil memuaskan dengan rata-rata kesalahan klasifikasi hanya sebesar 3.7-5.0\%.

\section{KESIMPULAN DAN SARAN}

Pada penelitian ini berhasil ditunjukkan aplikasi teknologi UV spectroscopy dan metode SIMCA untuk klasifikasi kopi Liberika Tungkal Jambi dan kopi Liberika Probolinggo. Dengan menggunakan perbaikan data spektra dan pemilihan interval panjang gelombang yang tepat, pemisahan kedua kopi Liberika berhasil dilakukan. Metode SIMCA memberikan konfirmasi pemisahan tersebut secara 
kuantitatif dengan akurasi klasifikasi sebesar 100\% untuk kedua kelas kopi Liberika yang diuji. Dengan harga spektrometer yang lebih terjangkau, pengembangan UV spectroscopy untuk uji keaslian kopi Liberika Tungkal Jambi sangat mungkin untuk dihilirisasi. Teknologi ini ke depan sangat potensial untuk digunakan dalam rangka memberikan perlindungan terhadap produk berkualitas andalan bangsa dari berbagai upaya pemalsuan.

\section{UCAPAN TERIMA KASIH}

Tim penulis mengucapkan terima kasih kepada Kementerian Riset dan Teknologi/ Badan Riset dan Inovasi Nasional (BRIN) Republik Indonesia atas dukungan pendanaan melalui hibah penelitian PKPT 2020-2022. Tim penulis juga mengucapkan terima kasih kepada seluruh pihak yang telah membantu pelaksanaan penelitian PKPT ini.

\section{DAFTAR PUSTAKA}

Aboulwafa, M. M., Youssef, F. S., Gad, H. A., Sarker, S. D., Nahar, L., Al-Azizi, M. M., \& Ashour, M. L. 2019. Authentication and discrimination of green tea samples using UV-vis, FTIR and HPLC techniques coupled with chemometrics analysis. Journal of Pharmaceutical and Biomedical Analysis, 164, 653-658. https://doi.org/ 10.1016/j.jpba.2018.11.036

Baqueta, M. R., Coqueiro, A., Março, P. H., \& Valderrama, P. 2021. Multivariate classification for the direct determination of cup profile in coffee blends via handheld near-infrared spectroscopy. Talanta, 222, 121526. https://doi.org/10.1016/ j.talanta.2020.121526

Dankowska, A., Domagala, A., \& Kowalewski, W. 2017. Quantification of Coffea arabica and Coffea canephora var. robusta concentration in blends by means of synchronous fluorescence and UV-Vis spectroscopies. Talanta, 172, 215-220. h t tp s://doi .org/10.1016/ j.talanta.2017.05.036
Davis, A. P., Tosh, J., Ruch, N., \& Fay, M. F. 2011. Growing coffee: Psilanthus (Rubiaceae) subsumed on the basis of molecular and morphological data; implications for the size, morphology, distribution and evolutionary history of Coffea. Botanical Journal of the Linnean Society, 167(4), 357-377. https://doi.org/10.1111/ j.1095-8339.2011.01177.x

DGIP. 2013. Buku Persyaratan Indikasi Geografis Masyarakat Perlindungan Indikasi Geografis (MPIG) Kopi Tungkal Jambi.

Keidel, A., Von Stetten, D., Rodrigues, C., Máguas, C., \& Hildebrandt, P. 2010. Discrimination of green arabica and Robusta coffee beans by Raman spectroscopy. Journal of Agricultural and Food Chemistry, 58(21), 11187-11192. https://doi.org/10.1021/ jf101999c

Meza-Márquez, O. G., Gallardo-Velázquez, T., \& Osorio-Revilla, G. 2010. Application of mid-infrared spectroscopy with multivariate analysis and soft independent modeling of class analogies (SIMCA) for the detection of adulterants in minced beef. Meat Science, 86(2), 511-519. h t tp s://doi.org / $10.1016 /$ j.meatsci.2010.05.044

Pomerantsev, A. L., \& Rodionova, O. Y. 2014. On the type II error in SIMCA method. Journal of Chemometrics, 28(6), 518-522. https:/ /doi.org/10.1002/cem.2610

Pomerantsev, A. L., \& Rodionova, O. Y. 2020. Popular decision rules in SIMCA: Critical review. Journal of Chemometrics, 34(8), 1-14. https://doi.org/10.1002/cem.3250

Roshan, A. R. A., Gad, H. A., El-Ahmady, S. H., Khanbash, M. S., Abou-Shoer, M. I., \& AlAzizi, M. M. 2013. Authentication of monofloral yemeni sidr honey using ultraviolet spectroscopy and chemometric analysis. Journal of Agricultural and Food Chemistry, 61(32), 7722-7729. https:// doi.org/10.1021/jf402280y 
Santos, K. M., Moura, M. F. V., Azevedo, F. G., Lima, K. M. G., Raimundo, I. M., \& Pasquini, C. 2012. Classification of Brazilian Coffee Using Near-Infrared Spectroscopy and Multivariate Calibration. Analytical Letters, 45(7), 774-781. https://doi.org/ 10.1080/00032719.2011.653905

Sianipar, H. 2017. Keragaman Genetik Populasi Kopi Liberika (Coffea Liberica W. Bull Ex. Hiern) Di Kecamatan Betara Berdasarkan Karakter Buah Dan Biji. Universitas Jambi.

Suhandy, D., \& Yulia, M. 2019. Classification of Ground Roasted Kalosi and Toraja Specialty Coffees using UV-Visible Spectroscopy and PLS-DA Method. Jurnal Ilmu Pertanian Indonesia, 24(1), 73-81. https://doi.org/10.18343/jipi.24.1.73

Suhandy, D., \& Yulia, M. 2018. Discrimination of several Indonesian specialty coffees using Fluorescence Spectroscopy combined with SIMCA method. IOP Conference Series: Materials Science and Engineering, 334(1). https://doi.org/10.1088/1757899X/334/1/012059
Suhandy, Diding, \& Yulia, M. 2017. Peaberry coffee discrimination using UV-visible spectroscopy combined with SIMCA and PLS-DA. International Journal of Food Properties, 20, S331-S339. https:// d o i . o r g / 100.1080 / 10942912.2017.1296861

Yulia, M., Asnaning, A. R., \& Suhandy, D. 2018. The Classification of Ground Roasted Decaffeinated Coffee Using UV-VIS Spectroscopy and SIMCA Method. IOP Conference Series: Earth and Environmental Science, 147(1). https:// doi.org/10.1088/1755-1315/147/1/ 012010

Yulia, M., \& Suhandy, D. 2018. Identification of fresh and expired ground roasted robusta coffee using UV-visible spectroscopy and chemometrics. MATEC Web of Conferences, 197. https://doi.org/ 10.1051/matecconf/201819709003 